\title{
41. CENOZOIC CLAY MINERALOGY OF SITES 604 AND 605, NEW JERSEY TRANSECT, DEEP SEA DRILLING PROJECT LEG 931
}

\author{
Dean A. Dunn, David M. Patrick, and Ulysses Cooley, Jr., Department of Geology, University of Southern \\ Mississippi ${ }^{2}$
}

\begin{abstract}
Examination of the clay mineralogy of Cenozoic sediment samples from Deep Sea Drilling Project Sites 604 and 605 on the upper continental rise off New Jersey indicates that sediment deposition of two different clay mineral facies has occurred. These sites are marked by Paleogene deposition of illite with subordinate kaolinite and smectite covarying in inverse proportion, and by Neogene deposition dominated by illite with subordinate kaolinite and chlorite. Leg 93 results agree with the clay mineral facies proposed by Hathaway (1972), which defined a "Northern facies" consisting of illite and chlorite, with feldspar and hornblende, from erosion of rocks north of Cape Hatteras, and a "Southern facies" composed of smectite, kaolinite, and mixed-layer illite-smectites. Neogene and Quaternary sediments at Sites 604 and 605 contain the "Northern facies," and Paleogene sediments contain the "Southern facies" minerals. Feldspar is exclusively found in Neogene-Quaternary sediments, as is the majority of the amphibole found in these samples. Widespread Paleogene volcanic source materials are suggested by the presence of smectite throughout the early Paleocenemiddle Eocene sediments recovered at Site 605. The clay mineral stratigraphy at Leg 93 sites is comparable to the record at nearby DSDP sites on the lower continental rise and abyssal plain of the northwestern Atlantic (DSDP Sites 388, 105, and 106), and also with the sediments recovered by drilling on the Mazagan Plateau off northwestern Morocco (DSDP Sites 544-547) in the eastern North Atlantic.
\end{abstract}

\section{INTRODUCTION}

Leg 93 drilled three holes at two sites on the proposed New Jersey Transect, which was scheduled to be completed by drilling on DSDP Leg 95 . The complete New Jersey Transect will provide a transect of drill holes across the continental margin off eastern North America. Two holes were drilled at Site 604 on the upper continental rise, in $2364 \mathrm{~m}$ (Hole 604) and $2340 \mathrm{~m}$ (Hole 604A) water depths, with both holes terminating in a Miocene slump deposit that was impenetrable by rotary drilling (See Sites 604/605 chapter, this volume). Site 605 was drilled at a 1.6-km offset to the northwest along USGS multichannel seismic line 25 (Fig. 1), at a water depth of $2197 \mathrm{~m}$. The location of Site 605 was successfully chosen to avoid the impenetrable Miocene lithologic unit, and to recover Paleogene sediments of the upper continental rise. By combining the cored sediments from Holes $604,604 \mathrm{~A}$, and 605 , it was possible to obtain a sediment history of the hemipelagic deposits of the New Jersey continental margin.

This study is a preliminary investigation of the Cenozoic clay mineralogy of Sites 604 and 605 . Samples of each lithologic unit defined by the shipboard sedimentologists were analyzed for their clay mineralogy in an attempt to determine if any temporal changes occurred in the clay content of Cenozoic hemipelagic sediments of the upper continental rise.

Deep-sea clay minerals are generally derived from continental sediments with little change in the crystalline

\footnotetext{
${ }^{1}$ van Hinte, J. E., Wise, S. W. Jr., et al., Init. Repts. DSDP, 93: Washington (U.S. Govt. Printing Office).

2 Address: Department of Geology, University of Southern Mississippi, Southern Station Box 5044, Hattiesburg, MS 39406-5044.
}

structure of the mineral (Biscaye, 1965). Fine-grained sediment materials are transported to continental margins by rivers and by aeolian transport, and this sediment is transported to hemipelagic and abyssal-plain depocenters by submarine slumping and turbidity currents. Thus deep-sea clay minerals may provide information on continental erosion and weathering (Biscaye, 1965). Chlorite is unstable, easily altered by chemical weathering, and is dominant in high-latitude marine sediments. Kaolinite is usually the result of intense chemical weathering and tends to be the dominant clay mineral in tropical latitudes. Detrital illite is the result of mechanical weathering of continental materials and tends to be found in river drainage patterns and in belts below the Jet Stream. Deep-sea clay minerals may also be formed in situ by authigenic processes, through the alteration of volcanic glass, or through neoformation of previous minerals (Millot, 1970). Smectite is an alteration product of volcanic materials, and tends to be more common in tropical to warm subtropical areas.

\section{SEDIMENTS EXAMINED IN THIS STUDY}

Drilling at Site 604 recovered three lithologic units of Pleistocene to late Miocene age (Table 1, Fig. 2). Lithologic Unit I, consisting of gray to greenish gray Pleistocene interbedded hemipelagic clay and silt layers, is divided into two subunits based on the presence or absence of slump structures. Unit II is late Miocene to Pleistocene greenish gray clay with variable amounts of glauconite and biogenic silica. Subunit IIA contains biogenic silicarich clay with glauconite sand intervals; Subunit IIB consists of silty clay with glauconite silt and sand particles. Subunit IIC is biogenic silica-bearing clay, and Subunit IID is biogenic silica-bearing glauconite-rich claystones and clayey siltstones. Lithologic Unit III at Site 604 was 

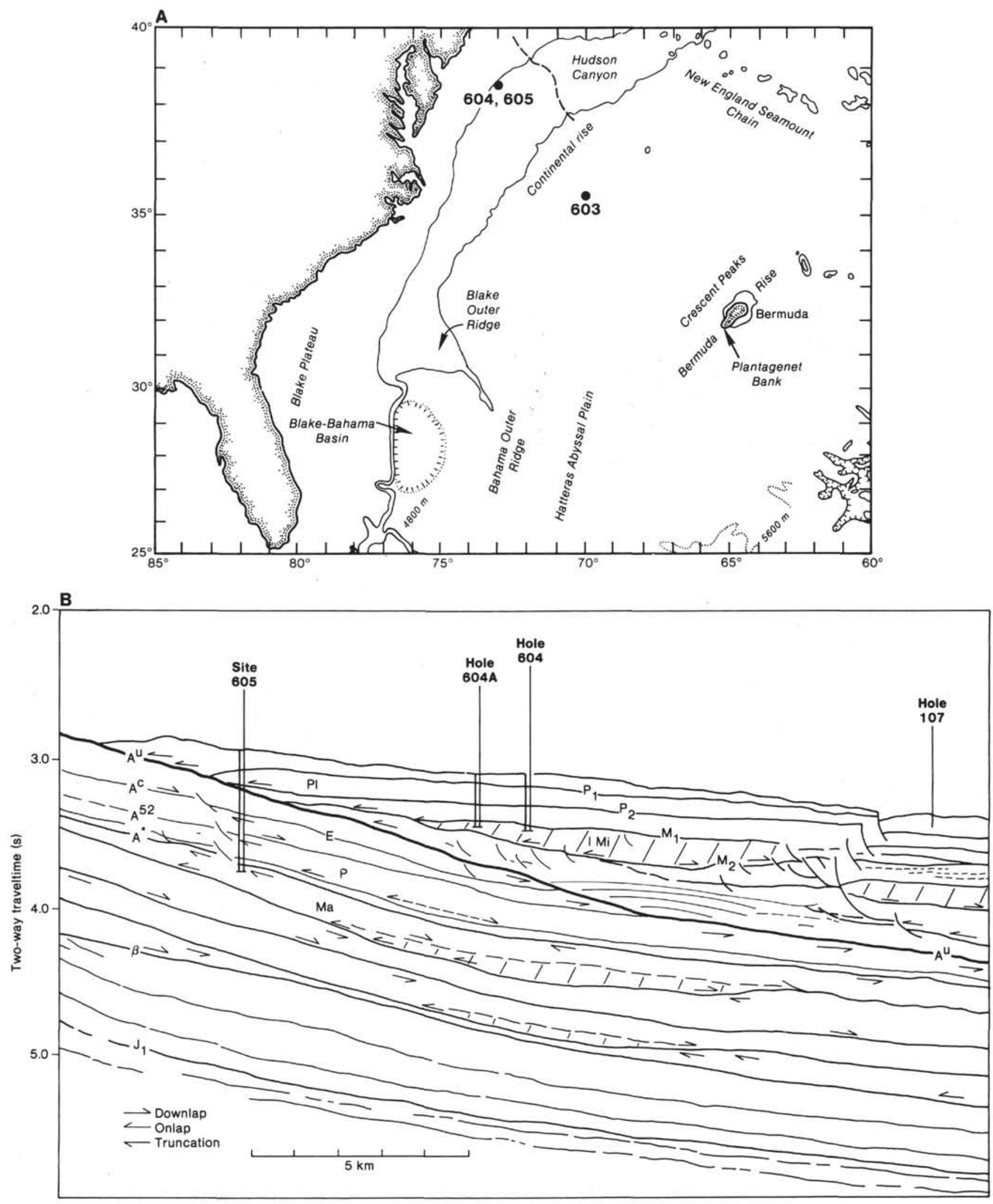

Figure 1. A. Location of sites drilled during Deep Sea Drilling Project Leg 93. B. Line drawing after USGS multichannel seismic reflection line 25 , indicating the locations of DSDP Hole 604, Hole 604A, and Site 605, and the relationship between seismostratigraphic units (see Sites 604/ 605 chapter, this volume) drilled at these sites. $\mathrm{P} 1=$ Pliocene-Pleistocene, $1 \mathrm{Mi}=$ late Miocene, $\mathrm{E}=\mathrm{Eocene}, \mathrm{P}=\mathrm{Paleocene}$, and $\mathrm{Ma}=$ Maestrichtian. 
Table 1. Site 604 lithostratigraphy.

\begin{tabular}{|c|c|c|c|c|c|}
\hline Unit & Subunit & Lithology & $\begin{array}{l}\text { Hole-Core-Section, } \\
\mathrm{cm} \text { level }\end{array}$ & $\begin{array}{l}\text { Sub-bottom } \\
\text { depth }(\mathrm{m})\end{array}$ & Age \\
\hline \multirow[t]{3}{*}{ I } & & Gray to dark greenish gray alternations & $\begin{array}{l}604-1 \text { to } \\
604-10-1,7 \mathrm{~cm}\end{array}$ & $0.0-84.0$ & $\begin{array}{l}\text { Late to middle } \\
\text { Pleistocene }\end{array}$ \\
\hline & IA & Interbedded clay and silt layers & $\begin{array}{l}604-1-1,0 \mathrm{~cm} \text { to } \\
604-5-1,0 \mathrm{~cm}\end{array}$ & $0.0-35.3$ & \\
\hline & IB & $\begin{array}{l}\text { Gray and dark greenish gray clay and silt } \\
\text { with slump structures }\end{array}$ & $\begin{array}{l}604-5-1,0 \mathrm{~cm} \text { to } \\
604-10-1,7 \mathrm{~cm}\end{array}$ & $35.3-84.0$ & \\
\hline \multirow[t]{5}{*}{ II } & & $\begin{array}{l}\text { Greenish gray clay with glauconite-rich } \\
\text { intervals and variable amounts of } \\
\text { biogenic silica }\end{array}$ & $\begin{array}{l}604-10-1,7 \mathrm{~cm} \text { to } \\
604-26-2,46 \mathrm{~cm}\end{array}$ & $84.0-238.9$ & $\begin{array}{l}\text { early Pleistocene- } \\
\text { latest Miocene }\end{array}$ \\
\hline & IIA & $\begin{array}{l}\text { Greenish gray clay with glauconite-rich } \\
\text { sand and biogenic silica }\end{array}$ & $\begin{array}{l}604-10-1,7 \mathrm{~cm} \\
\text { through } 604-13, C C\end{array}$ & $84.0-121.7$ & \\
\hline & IIB & $\begin{array}{l}\text { Greenish gray clay with glauconite-rich } \\
\text { sand }\end{array}$ & $\begin{array}{l}604-14 \text { through } \\
604-19, C C\end{array}$ & $121.7-179.3$ & \\
\hline & IIC & Greenish gray clay with biogenic silica & $\begin{array}{l}604-20 \text { through } \\
604-24, C C\end{array}$ & $179.3-227.3$ & \\
\hline & IID & $\begin{array}{l}\text { Greenish gray clay with glauconite-rich } \\
\text { sand and biogenic silica }\end{array}$ & $\begin{array}{l}604-25 \text { through } \\
604-26-2,46 \mathrm{~cm}\end{array}$ & $227.3-238.9$ & \\
\hline III & & $\begin{array}{l}\text { Glauconite- and biogenic silica-rich silty } \\
\text { claystone and conglomerates }\end{array}$ & $\begin{array}{l}604-26-2,46 \mathrm{~cm} \text { to } \\
604-31 \text { and } \\
604 \mathrm{~A}-2 \text { through } \\
604 \mathrm{~A}-4, \mathrm{CC}\end{array}$ & 238.9-294.5 & late Miocene \\
\hline
\end{tabular}

drilled for $55.6 \mathrm{~m}$, with extremely poor recovery (a total of $8.20 \mathrm{~m}$ of recovered sediment). This unit consists of a late Miocene debris-flow deposit, composed of glauconite-rich and biogenic silica-rich silty claystone and conglomerate, with rounded quartz pebbles, pebble- to cobble-sized clasts of Eocene limestone, and clay-rich biogenic silica-rich nannofossil chalk.

It is necessary to specify both the lithologic unit and the site number when referring to Leg 93 Sites 604 and 605 New Jersey Transect sediments. For example, lithologic Unit II of Site 604 differs both in lithology and age from Lithologic Unit II of Site 605. In addition, Site 605 was positioned so that Lithologic Unit III of Site 604 (the Miocene debris-flow deposits) was not penetrated at Site 605.

At Site 605, five different lithologic units were recovered, ranging in age from Pleistocene to Maestrichtian (Table 2, Fig. 2). Lithologic Unit I consists primarily of Pleistocene gray silt-rich clay (which approximately correlates with Subunits IA and IB of Site 604), and $24 \mathrm{~cm}$ of upper Pliocene green homogeneous, structureless, biogenic silica-bearing, calcareous-rich clay. Because of the extreme thinness of Lithologic Subunit IB at Site 605 (24 cm total thickness), no sample was taken from this unit. Erosion of sediments of late Eocene to early Pliocene age from this site produced a major unconformity at Site 605 (Fig. 2). Lithologic Unit II consists of greenish gray middle Eocene biogenic silica-rich nannofossil chalk. Unit III is early Eocene greenish gray nannofossil limestone, differentiated from the overlying unit only by its greater induration and lack of biogenic silica. Lithologic Unit IV consists of early to late Paleocene dark greenish gray clay-rich to clayey nannofossil limestone ("marl"). Unit V of Site 605 contains early Paleocene to latest late Maestrichtian olive gray terrigenous silt-rich foraminifer-nannofossil limestone, and late Maestrichtian olive gray clay-rich foraminifer-nannofossil limestone. No samples were analyzed from Subunit VB, as this entire subunit is of Cretaceous (late Maestrichtian) age.

\section{ANALYTICAL METHODS}

Sediment samples used in this study (Table 3 ) were examined and described using the criteria and sediment classification scheme devised by the Leg 93 shipboard sedimentologists (Dunn, this volume). Color was determined for samples prior to processing, using either the GSA Rock-Color charts or Munsell Sediment Color charts. Table 4 lists the samples examined in this study, their sub-bottom depths, age, color, and sediment name, determined in the laboratory by criteria used during Leg 93. Textural classification was determined by visual estimation of the grain size of sedimentary particles on smear slides, regardless of the composition of the sedimentary particles. For example, whole foraminifers were considered as sand-sized grains. The sediment name assigned to each lithology generally follows DSDP principles, but with certain modifications made by the Leg 93 shipboard sedimentologists (Dunn, this volume).

Although grain-size distributions were not determined for this study, the XRD data suggest that the sediment classifications determined by visual examination of smear slides have systematically overestimated the amount of clay present in the samples. Therefore, clayey silt or clayey siltstone may be more appropriate sediment names for those samples classified as clays or claystone.

Bulk (whole-rock) and oriented $(<2-\mu \mathrm{m})$ samples were examined by X-ray diffraction (XRD). Bulk samples were powdered and sieved through a $3.5-\phi(88 \mu \mathrm{m})$ screen; then the powdered and screened sample was sprinkled upon glass sample holders for XRD analysis. Sample disaggregation and dispersion to prepare oriented slides was accomplished by placing the sediment sample in a mechanical blender with distilled water for approximately two minutes, then samples were diluted and washed repeatedly with distilled water until dispersion occurred. No acids or dispersants were used. Two aliquots representing the $<2-\mu \mathrm{m}$ size fraction (based on Stokes Law settling) were decanted by pipette from the dispersed sample and placed upon glass slides. One slide was allowed to dry at room temperature and, upon drying, was used for the oriented, nonsolvated XRD analysis; the second slide was dried in an ethylene glycol environment for approximately 24 hours and was used for oriented and solvated XRD analysis (Carver, 1971).

XRD samples were analyzed using a General Electric Model 1200 $\mathrm{X}$-ray diffractometer. Samples were subjected to $\mathrm{Cu} \mathrm{K} \alpha$ radiation at a scanning rate of $2^{\circ} 2 \theta / \mathrm{min}$., and diffraction patterns were recorded on chart paper at a recording rate of $1 \mathrm{in.} / \mathrm{min}$.

Clay mineral identifications were made from diffractograms of the $<2-\mu \mathrm{m}$ fraction as follows: smectite by the presence of a $17-\AA$ A peak 


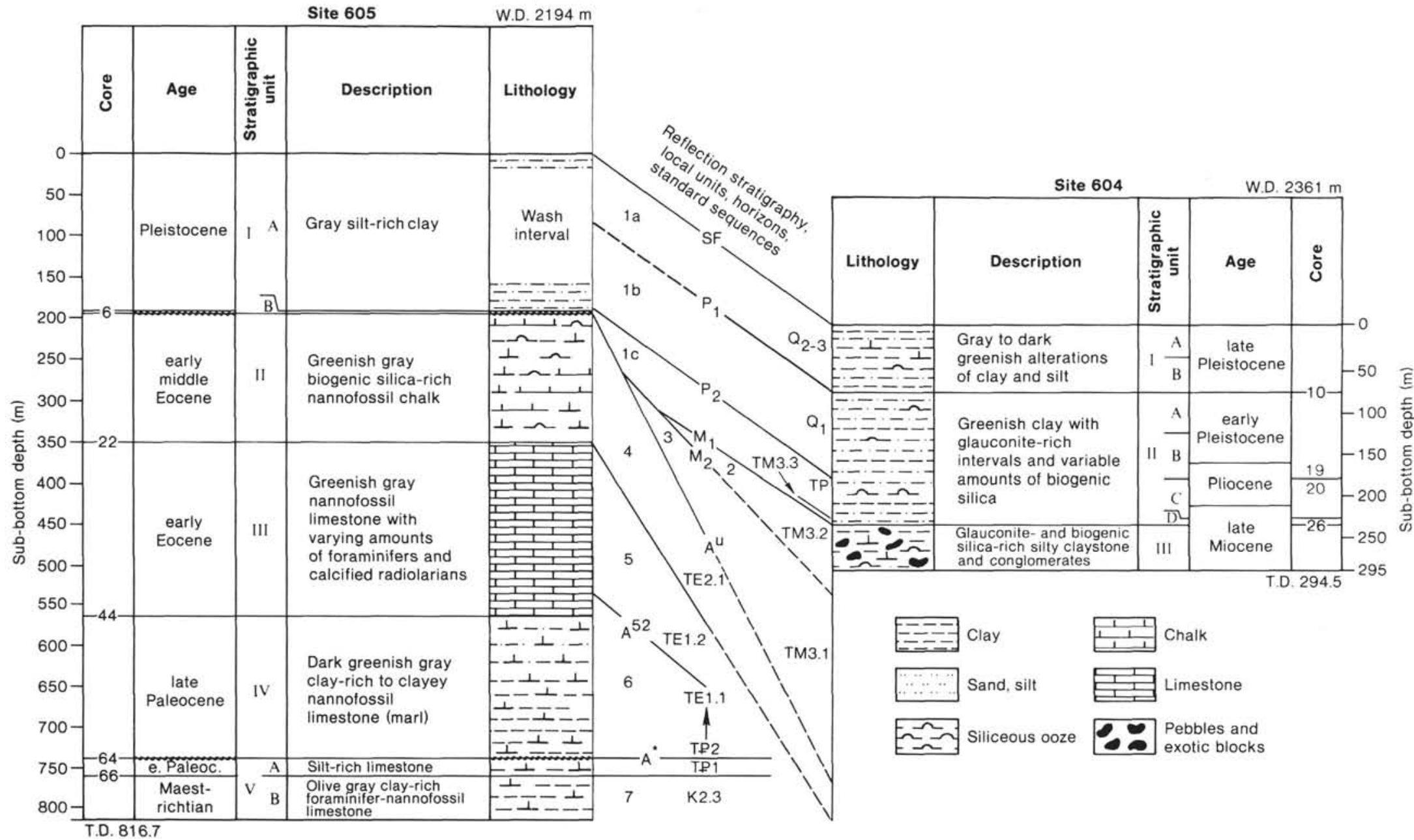

Figure 2. Stratigraphic summary of Sites 604 and 605 (from Sites 604/605 chapter, this volume). Units I to III (604) and I to V (605) are local lithostratigraphic units. Seismic reflection horizons drilled at Sites 604 and 605 are indicated (SF, $P_{1}, P_{2}, M_{1}, M_{2}, A^{u}, A^{c}, A^{52}$, and $A^{*}$. Standard seismic sequence notation after Vail et al. (1977). 
Table 2. Site 605 lithostratigraphy.

\begin{tabular}{|c|c|c|c|c|c|c|}
\hline Unit & Subunit & Lithology & $\begin{array}{l}\text { Hole-Core-Section, } \\
\mathrm{cm} \text { level or interval }\end{array}$ & $\begin{array}{l}\text { Sub-bottom } \\
\text { depth (m) }\end{array}$ & $\begin{array}{l}\text { Thickness } \\
(\mathrm{m})\end{array}$ & Age \\
\hline \multirow[t]{2}{*}{ I } & IA & Gray silt-rich clay & $\begin{array}{l}605-1 \text { to } \\
605-6-4,125 \mathrm{~cm}\end{array}$ & $0-198.00$ & 198.0 & Pleistocene \\
\hline & IB & $\begin{array}{l}\text { Green biogenic silica-bearing } \\
\text { calcareous-rich clay }\end{array}$ & $605-6-4,125-149 \mathrm{~cm}$ & $198.00-198.14$ & 0.14 & Pleistocene \\
\hline II & & $\begin{array}{l}\text { Greenish gray biogenic silica- } \\
\text { rich nannofossil chalk }\end{array}$ & $\begin{array}{l}605-6-4,149 \mathrm{~cm} \text { to } \\
605-22-3,50 \mathrm{~cm}\end{array}$ & $198.14-350.00$ & ca. 152 & lower middle Eocene \\
\hline III & & $\begin{array}{l}\text { Greenish gray nannofossil } \\
\text { limestone with varying } \\
\text { amounts of foraminifers and } \\
\text { calcified radiolarians }\end{array}$ & $\begin{array}{l}605-22-3,50 \mathrm{~cm} \text { to } \\
605-44-5,33 \mathrm{~cm}\end{array}$ & $350.00-564.00$ & 214 & $\begin{array}{l}\text { early middle Eocene to } \\
\text { earliest Eocene }\end{array}$ \\
\hline IV & & $\begin{array}{l}\text { Dark greenish gray clay-rich to } \\
\text { clayey nannofossil limestone } \\
\text { (marl) }\end{array}$ & $\begin{array}{l}605-44-5,33 \mathrm{~cm} \text { to } \\
605-64-1,54 \mathrm{~cm}\end{array}$ & $564.00-740.00$ & 184 & $\begin{array}{l}\text { late Paleocene to early } \\
\text { Paleocene }\end{array}$ \\
\hline \multirow[t]{3}{*}{ V } & & $\begin{array}{l}\text { Olive gray, silt-rich or foramini- } \\
\text { fer-rich, clayey nannofossil } \\
\text { limestone }\end{array}$ & $\begin{array}{l}605-64-1,54 \mathrm{~cm} \\
\text { through } 605-71, \mathrm{CC}\end{array}$ & $740.00-816.70$ & 77 & $\begin{array}{l}\text { early Paleocene to } \\
\text { middle Maestrichtian }\end{array}$ \\
\hline & VA & $\begin{array}{l}\text { Dark greenish gray, glauconite- } \\
\text { bearing and silt-rich nanno- } \\
\text { fossil clayey limestone }\end{array}$ & $\begin{array}{l}605-64-1,54 \mathrm{~cm} \text { to } \\
605-66-1,120 \mathrm{~cm}\end{array}$ & $740.40-760.20$ & 19.8 & $\begin{array}{c}\text { Paleocene to latest } \\
\text { Maestrichtian }\end{array}$ \\
\hline & VB & $\begin{array}{l}\text { Olive gray, clay-rich foramini- } \\
\text { fer-nannofossil limestone }\end{array}$ & $\begin{array}{c}605-66-1,120 \mathrm{~cm} \text { to } \\
605-71, \mathrm{CC}\end{array}$ & $760.20-816.70$ & 56.5 & Maestrichtian \\
\hline
\end{tabular}

Table 3. Lithologic units of Sites 604 and 605, and samples of each unit examined in this study.

\begin{tabular}{|c|c|c|c|}
\hline Unit & Subunit & Age & $\begin{array}{l}\text { Core-Section, } \\
\mathrm{cm} \text { level }\end{array}$ \\
\hline \multicolumn{4}{|l|}{ Site 604} \\
\hline 1 & & Pleistocene & \\
\hline & $\begin{array}{l}\text { IA } \\
\text { IB }\end{array}$ & & $\begin{array}{l}1-1,130 \\
6-3,130,8-2,57\end{array}$ \\
\hline II & & $\begin{array}{l}\text { early Pleistocene- } \\
\text { late Miocene }\end{array}$ & \\
\hline & IIA & & $10-4,100,13-1,106$ \\
\hline & IIB & & $16-4,100,18-4,100$ \\
\hline & IIC & & $22-2,100$ \\
\hline & IID & & $25-4,100$ \\
\hline III & & late Miocene & $27-1,140$ \\
\hline \multicolumn{4}{|l|}{ Site 605} \\
\hline 1 & & $\begin{array}{l}\text { Pleistocene- } \\
\text { late Pliocene }\end{array}$ & \\
\hline & IA & & $1-1,100,4-3,100$ \\
\hline & IB & & Not sampled \\
\hline II & & middle Eocene & $\begin{array}{c}7-6,100,15-2,100 \\
21-3,100\end{array}$ \\
\hline III & & early Eocene & $\begin{array}{c}27-1,100,33-5,100, \\
40-2,100\end{array}$ \\
\hline IV & & late-early Paleocene & $\begin{array}{c}48-4,100,54-1,100 \\
59-4,100\end{array}$ \\
\hline \multirow[t]{3}{*}{ V } & & $\begin{array}{l}\text { early Paleocene- } \\
\text { late Maestrichtian }\end{array}$ & \\
\hline & VA & & $64-3,100$ \\
\hline & VB & & Not sampled \\
\hline
\end{tabular}

after glycolation; illite by a $10-\AA ̊ .001$ peak on both oriented and glycolated diffractograms; chlorite by a $14-\AA$ peak after glycolation. Because a 7-A peak may be present on oriented diffractograms from either kaolinite (001 d-spacing) or chlorite (002 d-spacing), kaolinitechlorite proportions were based upon the relative areas under the $3.57-\hat{\AA}$ and $3.54-\AA$ peaks, respectively.

Clay mineral abundances were approximated from ratios between the peak areas of the different clay minerals, using the semiquantitative techniques of Biscaye (1965) and Carroll (1970). However, quantification of clay mineralogy from X-ray diffractograms is still only semiquantitative at best, because of variations between diffractometers, variance in the degree of orientation and crystallinity of clay minerals, and the possible presence of mixed-layer clay minerals. Our quantitative abundances have a precision of $\pm 10 \%$.
Semiquantitative estimates of the nonclay mineralogy of Sites 604 and 605 sediments, exclusive of cristobalite, glauconite, and amphibole, were made from diffractograms of bulk samples (Table 5), on the basis of unweighted peak areas and by assuming that the identified minerals composed $100 \%$ of the sample. Cristobalite and amphibole were identified from XRD data, but were not quantified, as the cristobalite peaks were broad and irregular and the abundance of amphibole was small. Glauconite was identified from smear slides made from Leg 93 samples, but was present in quantities less than or equal to $1 \%$. The presence of these minerals in Sites 604 and 605 samples are shown in Table 5 by an X.

\section{RESULTS}

\section{Bulk Mineralogy}

Estimates of nonclay mineral abundances of all samples examined in this study are shown in Table 5. Quartz and/or calcite predominate in all samples, and a small amount of feldspar is present in some samples of late Pliocene and younger age. Generally, calcite occurs in higher concentrations than quartz through the middle Eocene, after which quartz is the predominant nonclay mineral present. Quartz and calcite also occur in minor amounts in the $<2-\mu \mathrm{m}$ size fractions. One sample from the early Eocene $(605-27-1,100 \mathrm{~cm})$ contained a small amount of siderite.

The examination of smear slides did not reveal volcanic glass or other volcaniclastic components; however, silica polymorphs were identified by XRD in Site 605 samples from early Paleocene (Sample 605-59-4, $100 \mathrm{~cm}$ ) to middle Eocene age (Sample $605-15-2,100 \mathrm{~cm}$ ), and in one middle Pleistocene sample $(605-4-3,100 \mathrm{~cm})$. The identification was based upon rather broad XRD peaks representing d-spacings of approximately 4.00 to $4.07 \AA$ (Fig. 3); no secondary peaks were detected. These d-spacings are similar to those of both opal-A and opal-C. There was no XRD evidence of the presence of opal-CT or zeolites in these samples. Smear slides of the late Miocene sample $(604-27-1,140 \mathrm{~cm})$ and a middle Pleistocene sample $(605-4-3,100 \mathrm{~cm})$ contained glauconite.

The presence of amphibole was indicated by peaks on the X-ray diffractograms of one upper Paleocene sample 
Table 4. Sub-bottom depth, age, lithology, and color of samples examined in this study.

\begin{tabular}{|c|c|c|c|c|}
\hline $\begin{array}{c}\text { Core-Section, } \\
\mathrm{cm} \text { level }\end{array}$ & Depth (m) & Age & Sediment name & Color \\
\hline \multicolumn{5}{|l|}{ Site 604} \\
\hline $1-1,130$ & 1.32 & late Pleistocene & Quartz-rich, nannofossil-bearing silty clay & Olive gray $(5 \mathrm{Y} 5 / 2)$ \\
\hline $6-3,130$ & 49.20 & late Pleistocene & Foraminifer-bearing silty clay & Grayish green $(5 \mathrm{GY} 4 / 2)$ \\
\hline $8-2,57$ & 66.19 & late Pleistocene & Carbonate-bearing, silt-rich clay & Dark greenish gray $(5 \mathrm{GY} 4 / 1)$ \\
\hline $10-4,100$ & 88.82 & early Pleistocene & Glauconite-bearing, nannofossil-rich clay & Dark greenish gray $(5 \mathrm{Y} 4 / 1)$ \\
\hline $13-1,106$ & 113.16 & early Pleistocene & Carbonate-bearing silty clay & Greenish gray $(5 \mathrm{GY} 4 / 1)$ \\
\hline $16-4,100$ & 146.40 & early Pleistocene & Carbonate-rich silty clay & Greenish gray (5GY4/1) \\
\hline $18-4,100$ & 165.62 & late Pliocene & Nannofossil-bearing silty clay & Dark greenish gray $(5 \mathrm{GY} 5 / 1)$ \\
\hline $22-2,100$ & 201.00 & early Pliocene & Biogenic silica-bearing nannofossil-rich clay & Dark greenish-gray $(5 \mathrm{GY} 4 / 1)$ \\
\hline $25-4,100$ & 232.82 & early Pliocene & Nannofossil-rich claystone & Dark grayish green $(5 \mathrm{GY} 3 / 2)$ \\
\hline $27-1,140$ & 247.92 & late Miocene & Glauconite-rich clayey sandy siltstone & Dark greenish gray $(5 \mathrm{GY} 3 / 1)$ \\
\hline \multicolumn{5}{|l|}{ Site 605} \\
\hline $1-1,100$ & $? ?$ & middle Pleistocene & Biogenic silica- and carbonate-bearing clay & Medium gray (N5) \\
\hline $4-3,100$ & 177.52 & middle Pleistocene & Carbonate- and quartz silt-rich clay & Dark gray (N4) \\
\hline $7-6,100$ & 210.82 & middle Eocene & Biogenic silica-rich nannofossil chalk & Light greenish-gray $(5 \mathrm{GY} 7 / 1)$ \\
\hline $15-2,100$ & 281.70 & middle Eocene & Biogenic silica-rich nannofossil chalk & Light greenish gray $(5 \mathrm{GY} 7 / 1$ \\
\hline $21-3,100$ & 340.70 & middle Eocene & Biogenic silica-rich nannofossil chalk & Light greenish gray $(5 \mathrm{GY} 7 / 1)$ \\
\hline $27-1,100$ & 395.30 & early Eocene & Foraminifer-bearing nannofossil limestone & Greenish gray $(5 \mathrm{GY} 6 / 1)$ \\
\hline $33-5,100$ & 458.92 & early Eocene & Foraminifer- and clay-bearing nannofossil limestone & Light greenish gray $(5 \mathrm{GY} 7 / 1)$ \\
\hline $40-2,100$ & 521.60 & early Eocene & Foraminifer-bearing clay-rich nannofossil limestone & Pale green $(10 \mathrm{G} 6 / 2)$ \\
\hline $48-4,100$ & 601.42 & late Paleocene & Clayey nannofossil limestone & Greenish gray $(5 \mathrm{GY} 4 / 1-5 \mathrm{GY} 5 / 1)$ \\
\hline $54-1,100$ & 649.40 & late Paleocene & Foraminifer-bearing clayey nannofossil limestone & Gray (N5) \\
\hline $59-4,100$ & 697.40 & early Paleocene & Clayey nannofossil limestone & Dark greenish gray $(5 \mathrm{GY} 4 / 1)$ \\
\hline $64-3,100$ & 743.92 & early Paleocene & Quartz-bearing, clay-rich nannofossil limestone & Greenish-gray $(5 \mathrm{GY} 6 / 1)$ \\
\hline
\end{tabular}

(605-48-4, $100 \mathrm{~cm})$, one upper Pliocene sample (604-18-4, $100 \mathrm{~cm}$ ), and samples of middle to late Pleistocene age at both sites.

The total abundance of clay minerals relative to nonclay minerals in bulk samples was not determined; however, clay mineral peaks on the diffractograms of bulk samples were extremely weak or absent, suggesting that these minerals do not compose an appreciable proportion of the total sample.

\section{Clay Mineralogy}

The relative proportions of kaolinite, chlorite, illite, and smectite are given in Table 6, and are plotted in Figure 4 . The occurrence of these minerals is discussed below. Kaolinite occurred in all samples except one from the lower Paleocene and one of early Eocene age. The proportion of kaolinite was high in Paleocene samples, decreased to a minimum value in the uppermost middle Eocene sample, then reached peak abundances (36-45\%) during the late Miocene to early Pliocene. Following these peak values, kaolinite abundances remained relatively constant through the late Pliocene to late Pleistocene, ranging from 10 to $25 \%$ of the total clay mineral assemblages of these sediments. The 001 peaks were rather broad, indicating a low degree of crystallinity.

Minor amounts $(<15 \%)$ of chlorite were found in one late Paleocene sample from lithologic Unit IV and two early Eocene samples from lithologic Unit III of Site 605 (Fig. 2). Chlorite was not present in the middle Eocene biogenic silica-rich chalks (lithologic Unit II) of Site 605 , or in samples of early Pliocene sediments, whereas late Pliocene and younger sediments at both sites contained significant amounts of this clay mineral (Fig. 5). Maximum values (29-32\%) were found in middle to late Pleistocene sediments at both sites. As with kaolinite, peaks were broad and low; some mixed-layer chloritesmectite was indicated by separation of $14-\AA$ p peaks and slight shift to lower 2- $\theta$ spacings upon glycolation.

Illite was present in the $<2-\mu \mathrm{m}$ fraction of all samples and predominated in most. An early Eocene limestone sample $(605-33-5,100 \mathrm{~cm})$ was exclusively illitic (Fig. 4). Most 001 peaks were rather low and broad, and low 2- $\theta$ shoulders on the 001 peaks for most samples suggested some mixed-layer illite-smectite (Fig. 6). Some proportion of the illite may represent glauconite that was visually identified in two of the samples (604-27-1, 140 $\mathrm{cm}$ and $605-4-3,100 \mathrm{~cm}$ ).

Smectite was mainly limited to Paleogene samples, although one early Pliocene sample $(604-25-4,100 \mathrm{~cm})$ and one late Pleistocene sample $(604-1-1,100 \mathrm{~cm})$ contained this mineral. Much smectite was present in an early Paleocene sample (605-64-3, $100 \mathrm{~cm})$, and predominated in late Paleocene $(605-48-4,100 \mathrm{~cm})$ and middle Eocene $(605-7-6,100 \mathrm{~cm})$ samples. For untreated slides the 001 peaks were low and broad; however, ethylene glycol solvation produced distinct $17-\AA ̊ \AA 001$ peaks (Fig. 7).

\section{DISCUSSION}

\section{New Jersey Transect Sedimentology}

Olsson (1978) divides the eastern coastal plain Tertiary sediments into two sequences separated by a disconformity: a lower Paleogene (Paleocene-middle Eocene) unit composed of glauconite-rich sand, silt, and clay strata, and a Neogene unit of fine- to coarse-grained sands and gravels, with some clay interbeds. These two sedimentary units are separated by a disconformity that may be the result of a major Eocene transgression followed by regressive offlap at the middle/late Eocene boundary, caused by severe climatic cooling and lower- 
Table 5. Proportions of nonclay minerals in samples arranged by geologic age.

\begin{tabular}{|c|c|c|c|c|c|c|c|}
\hline \multirow{2}{*}{$\begin{array}{c}\text { Hole-Core-Section, } \\
\mathrm{cm} \text { level }\end{array}$} & \multicolumn{7}{|c|}{ Nonclay mineralogy ${ }^{* a}$} \\
\hline & QTZ & CAL & FSP & SID & GLC & CRST & AMPH \\
\hline \multicolumn{8}{|l|}{ late Pleistocene } \\
\hline $604-1-1,130$ & 81 & 7 & 12 & - & - & - & $\mathrm{x}$ \\
\hline $604-6-3,130$ & 48 & 21 & 31 & - & - & - & $\mathrm{x}$ \\
\hline $604-8 \cdot 2,57$ & 73 & 12 & 15 & - & - & - & - \\
\hline \multicolumn{8}{|l|}{ middle Pleistocene } \\
\hline $605-1-1,100$ & 100 & - & - & - & - & - & - \\
\hline $605-4-3,100$ & 57 & 16 & 26 & - & $\mathrm{x}$ & $\mathrm{x}$ & $\mathrm{x}$ \\
\hline \multicolumn{8}{|l|}{ early Pleistocene } \\
\hline $604-10-4,100$ & 100 & - & - & - & - & - & - \\
\hline $604-13-1,106$ & 55 & 14 & 31 & - & - & - & - \\
\hline \multicolumn{8}{|l|}{ late Pliocene } \\
\hline $604-16-4,100$ & 80 & 6 & 14 & - & - & - & - \\
\hline $604-18-4,100$ & 77 & 13 & 10 & - & - & - & $\mathrm{x}$ \\
\hline \multicolumn{8}{|l|}{ early Pliocene } \\
\hline $604-22-2,100$ & 70 & 30 & - & - & - & - & - \\
\hline $604-25-4,100$ & 100 & - & - & - & - & - & - \\
\hline \multicolumn{8}{|l|}{ late Miocene } \\
\hline $604-27-1,140$ & 100 & - & - & - & $\mathrm{x}$ & - & - \\
\hline \multicolumn{8}{|l|}{ middle Eocene } \\
\hline $605-7 \cdot 6,100$ & - & 100 & - & - & - & - & - \\
\hline $605-15-2,100$ & - & 100 & - & - & - & $\mathrm{x}$ & - \\
\hline $605-21-3,100$ & - & 100 & - & - & - & $\mathrm{x}$ & - \\
\hline \multicolumn{8}{|l|}{ early Eocene } \\
\hline $605-27-1,100$ & - & 90 & - & 10 & - & $\mathrm{x}$ & - \\
\hline $605-33-5,100$ & 14 & 86 & - & - & - & $\hat{x}$ & - \\
\hline $605-40-2,100$ & 32 & 68 & - & - & - & $\mathrm{x}$ & - \\
\hline \multicolumn{8}{|l|}{ late Paleocene } \\
\hline $605-48-4,100$ & 45 & 55 & - & - & - & - & $\mathrm{x}$ \\
\hline $605-54-1,100$ & 39 & 61 & - & - & - & $\mathrm{x}$ & - \\
\hline \multicolumn{8}{|l|}{ early Paleocene } \\
\hline $605-59-4,100$ & 42 & 58 & - & - & - & $\mathrm{x}$ & - \\
\hline $605-64-3,100$ & 57 & 43 & - & - & - & - & - \\
\hline
\end{tabular}

Note: Dashed rule indicates no samples of late Eocene to middle Miocene age recov* ered. - indicates searched for but not found.

*a Key to mineral codes: QTZ: Quartz; CAL: calcite; FSP: feldspar; SID: siderite; GLC: glauconite; CRST: cristobalite; and AMPH: amphibole. $\mathrm{X}=$ present, but not quantified.

ing of sea levels (Ingle et al., 1976). Following this Eocene cooling, a late Oligocene to earliest Miocene warming (Haq and Lohmann, 1976) caused the deposition of transgressive sediments atop the disconformity.

The sediments drilled at Sites 604 and 605 generally show the stratigraphic division described by Olsson (1978), having two different lithologies separated by a middle to late Eocene disconformity. At Site 605, Maestrichtian to Paleocene marls, early Eocene nannofossil limestones, and middle Eocene biogenic silica-rich nannofossil chalks are separated by a disconformity from late Pliocene-Pleistocene silty clays and claystones. Lithologic Unit I of Site 605 was cored for only $34.24 \mathrm{~m}$, and the hole was washed through for most of its thickness, as these Pliocene-Pleistocene silty clays and claystones were continu- ously cored at Site 604 . Underlying these silty clays and claystones at Site 604 was a middle to late Miocene slump deposit that was impenetrable by rotary drilling, so we were unable to determine the age and nature of the seismostratigraphic unit immediately below the slump deposits (Fig. 1). Thus we were unable to determine at Site 604 the age or nature of the disconformity that corresponds to the one drilled at Site 605 .

The major change in sediment types across the disconformity at Site 605 may be either related to a change in the carbonate compensation depth (CCD) or the result of increased continental erosion that provided greater supplies of terrigenous material. There are insufficient numbers of drill holes this close to the North American continent in this area to permit definition of the CCD. The Cenozoic CCD record for this region of the deep Atlantic is well-known (Jansa et al., 1979), but the information is of little assistance in the analysis of nearcontinent CCD levels, as it is known that the CCD typically shoals near continents.

The change from calcareous lithologies to silty clays and claystones across the disconformity at Site 605 may be due to increased input of terrigenous debris to the upper continental rise in conjunction with changes in sedimentation created by the Western Boundary Undercurrent (WBUC). Heezen et al. (1966) and Lancelot et al. (1972) have documented the building of a depositional sedimentary ridge at the foot of the continental slope along the northeastern margin of the United States during the Miocene-Pliocene, caused by deposition of hemipelagic muds that had been reworked by the WBUC. The formation of these lower continental rise sediments during the Miocene must have been related to an increase in the supply of terrigenous silts from North America (Asquith, 1979), so it seems reasonable to assume that a change in the sediment supply to the lower continental rise could also have affected the upper continental rise sediments cored during Leg 93.

\section{New Jersey Transect Clay Mineralogy}

Generally, the clay mineral suite at Sites 604 and 605 is considered to represent both inherited (detrital) and neoformed (authigenic) origins (Millot, 1970). The kaolinite is believed to be exclusively inherited from continental sources to the west. These sources (soils and reworked sediments) had originated under relatively humid-warm climatic conditions that culminated in the late Miocene-early Pliocene. At nearby DSDP Hole 388A on the lower continental rise, tropical to subtropical radiolarians (Orosphaerids and Collosphaerids) were found only in middle Miocene sediments (Weaver and Dinkelman, 1978), indicating a warm middle Miocene climate on the eastern United States Continental margin.

From the late Pliocene through the Pleistocene, kaolinite was apparently no longer forming on the continents, due to lowered continental paleotemperatures during glacial episodes; kaolinite in late Pliocene and Pleistocene sediments is thought to have originated by reworking of older sediments. Generally, kaolinite abundances in these sediments are lower than those of Paleocene to Miocene age (Fig. 4). The inherited origin of the kaolin- 


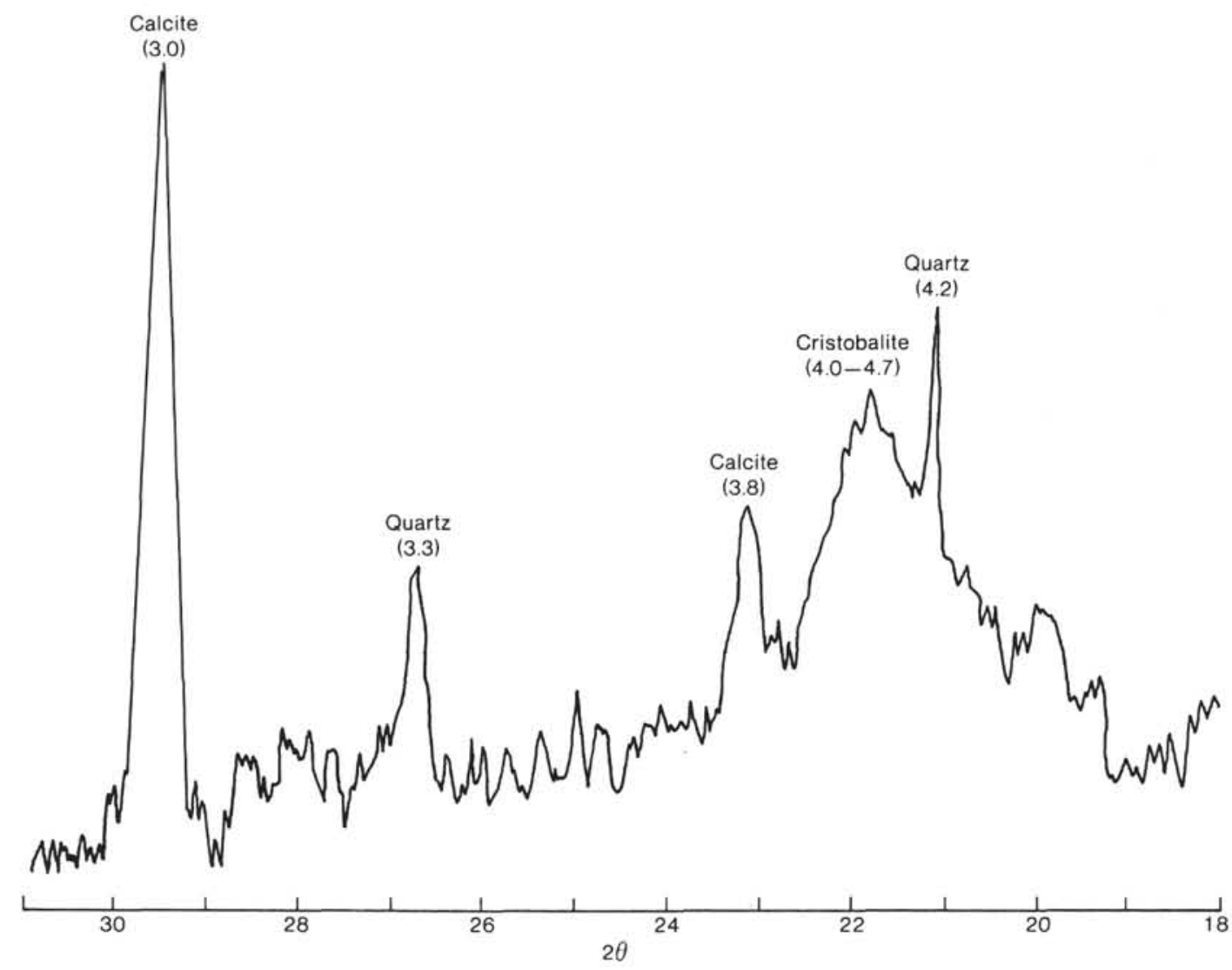

Figure 3. X-ray diffractogram of the bulk fraction of Sample 605-33-5, $100 \mathrm{~cm}$, illustrating typical broad XRD peaks between 4.00 and $4.07 \AA$ seen in Leg 93 samples and identified as cristobalite. Also seen are two calcite XRD peaks (3.0 and $3.8 \AA$ ) and two quartz peaks (3.3 and $4.2 \AA$ ).

ite is supported by the presence of accompanying detrital quartz and feldspar. There is no evidence to support neoformation of kaolinite in such an ion-rich marine environment. However, neoformation of kaolinite is best observed petrographically or by using scanning electron microscopy, so these avenues should be addressed in later studies.

The chlorite is presumed to be primarily inherited. The first consistent occurrence of this mineral in the early Pliocene must be related to changing climatic conditions and the beginning of Pleistocene glaciation. During these times kaolinization was decreasing due to lowered temperatures, and glaciers were transporting large quantities of chlorite and illite to the south from igneous and metamorphic sources on the Canadian Shield.

The origin of the illite may be primarily by inheritance. No doubt some of the illite originated in the same manner as the kaolinite and accompanied the latter from the same or a nearby source area. However, the presence of glauconite grains in smear slides of late Miocene and middle Pliocene samples suggests that clay minerals were being either neoformed or transformed by the processes of glauconitization. Probably a part of the material identified as illite at Sites 604 and 605 samples is really glauconite.

Smectite may also be contained in glauconite; however, those samples described as glauconitic from observations of smear slides did not contain smectite. There- fore, one is forced to the conclusion that appreciable smectite did not originate with glauconite but rather represents inheritance and/or neoformation from the devitrification of volcanic ash. The latter origin would be better substantiated if quantities of volcaniclastic materials such as volcanic ash were present.

\section{Leg 93 Volcanogenic Minerals}

The rather irregular stratigraphic distribution of smectite may support neoformation rather than inheritance and may reflect periodic ash falls in the region. A middle Eocene rhyodacite to rhyolite ash layer found in Sample $605-21-2,145-147 \mathrm{~cm}$ and dated at 40 to $45 \mathrm{Ma}$ by $\mathrm{K} / \mathrm{Ar}$ methods (von Rad and Kreuzer, this volume) was the only megascopic evidence of volcanism found at Site 605 . The presence of silica polymorphs in Site 605 samples suggests volcanic activity; however, the inability to distinguish inorganic, high temperature opal-C from biogenic opal-A precludes the establishment of a positive relationship between a silica polymorph and volcanism (Kastner, 1979).

A number of potential volcanic source areas in the North Atlantic may explain the presence of Paleogene volcanogenic minerals (smectite and possibly cristobalite), including the New England Seamount chain to the east, and Bermuda to the southeast of Site 605 . The age of New England Seamount volcanism has been estimated at 110 to $85 \mathrm{Ma}$ (Gradstein and Sheridan, 1983), with 
Table 6. Proportions of clay minerals in $<2-\mu \mathrm{m}$ fraction in samples examined for this study.

\begin{tabular}{|c|c|c|c|c|}
\hline \multirow{2}{*}{$\begin{array}{l}\text { Hole-Core-Section, } \\
\mathrm{cm} \text { level }\end{array}$} & \multicolumn{4}{|c|}{ Clay minerals $(\%)$} \\
\hline & Kaolinite & Chlorite & Illite & Smectite \\
\hline \multicolumn{5}{|l|}{ late Pleistocene } \\
\hline $604-1-1,130$ & 12 & 15 & 66 & 7 \\
\hline $604-6-3,130$ & 25 & 32 & 43 & - \\
\hline $604-8-2,57$ & 23 & 23 & 54 & - \\
\hline \multicolumn{5}{|l|}{ middle Pleistocene } \\
\hline $605-1-1,100$ & 10 & 32 & 58 & - \\
\hline $605-4-3,100$ & 6 & 29 & 65 & - \\
\hline \multicolumn{5}{|l|}{ early Pleistocene } \\
\hline $604-10-4,100$ & 24 & 13 & 63 & - \\
\hline $605-13-1,106$ & 17 & 19 & 64 & - \\
\hline \multicolumn{5}{|l|}{ late Pliocene } \\
\hline $604-16-4,100$ & 16 & 17 & 67 & - \\
\hline $604-18-4,100$ & 5 & 22 & 73 & - \\
\hline \multicolumn{5}{|l|}{ early Pliocene } \\
\hline $604-22-2,100$ & 9 & 24 & 67 & - \\
\hline $604-25-4,100$ & 45 & - & 41 & 14 \\
\hline \multicolumn{5}{|l|}{ late Miocene } \\
\hline $604-27-1,140$ & 36 & - & 64 & - \\
\hline \multicolumn{5}{|l|}{ middle Eocene } \\
\hline $605-7-6,100$ & 5 & - & 32 & 63 \\
\hline $605-15-2,100$ & 48 & - & 45 & 7 \\
\hline $605-21-3,100$ & 35 & - & 65 & - \\
\hline \multicolumn{5}{|l|}{ early Eocene } \\
\hline $605-27-1,100$ & 24 & 9 & 67 & - \\
\hline $605-33-5,100$ & - & - & 100 & - \\
\hline $605-40-2,100$ & 19 & 14 & 67 & - \\
\hline \multicolumn{5}{|l|}{ late Paleocene } \\
\hline $605-48-4,100$ & 16 & - & 33 & 51 \\
\hline $605-54-1,100$ & 40 & 7 & 53 & - \\
\hline \multicolumn{5}{|l|}{ early Paleocene } \\
\hline $605-59-4,100$ & 43 & - & 57 & - \\
\hline $605-64-3,100$ & - & - & 58 & 42 \\
\hline
\end{tabular}

the "latest significant volcanism" occurring in the early Campanian (78-74 Ma) (Vogt and Tucholke, 1979). The seamounts of the New England Seamount chain were drilled by DSDP Leg 43 (Tucholke, Vogt, et al., 1979), and the easternmost peak of this chain (Nashville Seamount) contained basaltic clasts from volcaniclastic breccias that were dated at $79 \pm 4$ to $88.3 \pm 5.7 \mathrm{Ma}$ by ${ }^{40} \mathrm{Ar}$ / ${ }^{39} \mathrm{Ar}$ and by $\mathrm{K} / \mathrm{Ar}$ dating (Houghton et al., 1979). Reworking of Late Cretaceous volcanic ash produced by eruptions of the New England Seamounts may have produced the Paleogene volcanic alteration minerals found at Site 605 . More-weathered volcaniclastic breccias at Site 385 (Vogel Seamount of the New England Seamount chain) were dated by Houghton et al. (1979) at $38.3 \pm$ 15 to $91.2 \pm 3 \mathrm{Ma}$, an age range in agreement with the Paleocene to middle Eocene cristobalites at Site 605 .

Another potential source for Site 605 volcaniclastics is volcanic products from Bermuda volcanoes. Vogt and Tucholke (1979) indicate that the main Bermuda tholeiitic shield volcanoes had been built above sea level by the Late Paleocene (45 Ma). Abundant evidence is found for the deposition of middle Eocene volcaniclastic material at Site 605 , including the rhyodacitic-rhyolitic ash layer in Sample 605-21-2, 145-147 cm, and the increased smectite abundances in the middle Eocene samples (605$15-2,100 \mathrm{~cm}$ and $605-7-6,100 \mathrm{~cm}$ ) examined in this study. Gradstein and Sheridan (1983) indicate that Bermuda volcanism occurred between the late Eocene and middle Oligocene (50-30 Ma).

Periodic occurrences of possible volcanogenic materials are found in the Neogene to Quaternary sediments of the New Jersey Transect, including early Pliocene smectite and zeolites (604-25-4, $100 \mathrm{~cm}$ and 605-22-2, 100 $\mathrm{cm}$ ), middle Pleistocene zeolites and cristobalite (605-4$3,100 \mathrm{~cm}$ ), and late Pleistocene smectite and zeolites $(604-6-3,130 \mathrm{~cm}$ and $604-1-1,130 \mathrm{~cm})$. A number of potential volcanic sources for these materials exists, including Miocene (25-5 Ma) volcanism related to the uplift of the Moroccan Atlas Mountains (Gradstein and Sheridan, 1983) and Miocene volcanism in the Canary Islands, Biscay Seamount, the Cape Verde Islands, and Iceland (Houghton et al., 1979). The Azores Islands are still actively volcanic (Vogt and Tucholke, 1979), but were intermittently active from the early or middle Miocene (19-15 Ma; Anguita and Hernan, 1975). A Miocene basaltic sill recovered at Site 382 on the Sohm Abyssal Plain to the southeast of the Leg 93 sites was dated at $21.0 \pm 3$ Ma by whole-rock potassium-argon methods (Houghton et al., 1979). This sill was geochemically similar to another Miocene sill recovered at DSDP Site 10 to the southeast, which was dated at $15.9 \pm 1.6 \mathrm{Ma}$ by fission-track dating (MacDougall, 1971).

\section{Leg 93 Clay Mineral Facies}

Hathaway (1972) described two major clay mineral facies on the continental margin of the eastern United States: a "Northern facies," consisting of illite, chlorite, and traces of feldspar and hornblende, and a "Southern facies," composed of montmorillonite and kaolinite (including mixed-layer montmorillonite-illite and dioctahedral vermiculite). The presence of the "Northern facies" was interpreted as being the result of clay minerals, derived from glacial sources to the north, which moved southward out of estuary mouths along the continental shelf and passed to the continental rise by submarine canyon transport. Of the clay minerals composing the "Southern facies," illite was found only in rivers to the north of Chesapeake Bay, and montmorillonite was found mainly in rivers to the south of the Pamlico Sound estuary in North Carolina. Vermiculite was found to be common to both the northern and southern mineral assemblages, with a maximum in the Pamlico Sound estuary, which approximately divides the sources of the "North- 

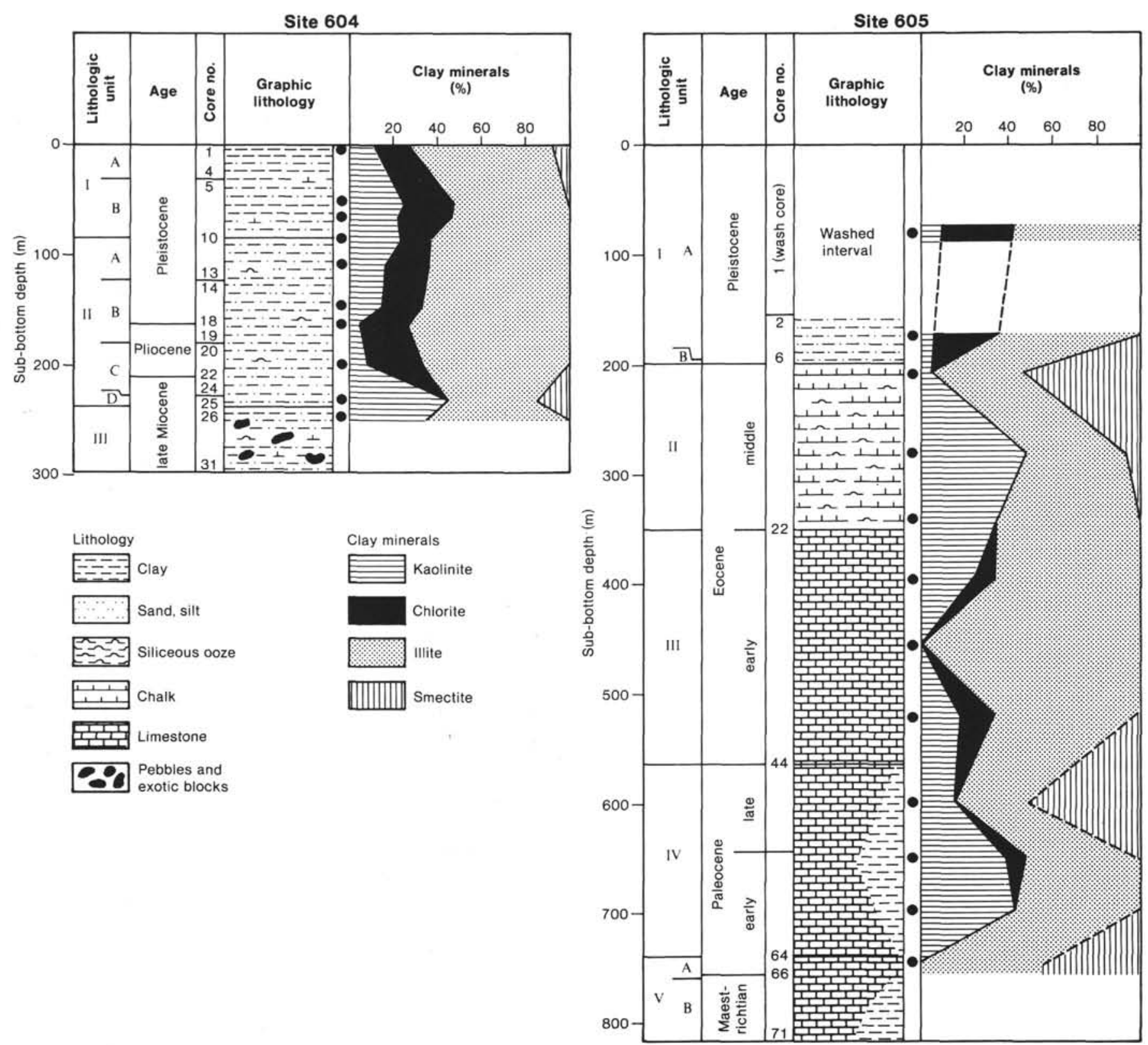

Figure 4. Cenozoic clay mineralogy, graphic lithology, and lithostratigraphy of DSDP Sites 604 and 605 . Sample locations are indicated by large dots next to the graphic lithology columns.

ern" and "Southern clay mineral facies." No dioctahedral vermiculite was found to the north of the Chesapeake Bay estuary.

The distribution of clay minerals in the Leg $93 \mathrm{New}$ Jersey Transect sites parallels that discussed in Hathaway (1972), as clay minerals of the post-middle Miocene sediments are similar to the "Northern facies," with dominant illite, plus chlorite, feldspar, and amphibole. No feldspar was found in sediments older than Miocene age, and only one occurrence of amphibole was found in Paleogene sediments (late Paleocene Sample 605-48-4, 100 $\mathrm{cm})$. Because chlorite and feldspar are readily susceptible to chemical weathering (Biscaye, 1965), their presence in post-middle Miocene sediments at Sites 604 and 605 may reflect glacial erosion of the Appalachian
Mountains, with relatively unweathered minerals being carried to the edge of the North American continent by the ancestral Hudson, Delaware, and other rivers emptying into the northwestern Atlantic Ocean.

Although the Paleogene clay mineralogy of Site 605 is generally similar to the "Southern facies" of smectite, kaolinite, and mixed-layer illite-smectite (Hathaway, 1972), there are differences between Site 605 Paleogene mineralogy and Hathaway's model. At Site 605, Paleogene sediments are dominated by illite, with kaolinite and smectite covarying in inverse proportions to each other (Fig. 4), a pattern in overall agreement with that of the "Southern clay mineral facies." However, significant quantities $(7-15 \%)$ of chlorite were present in late Paleocene and early Eocene samples at Site 605, in contrast to the Ha- 
$<2-\mu \mathrm{m}$ oriented

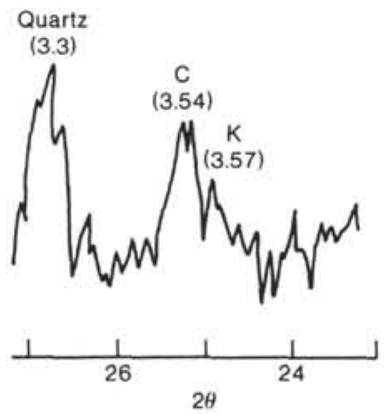

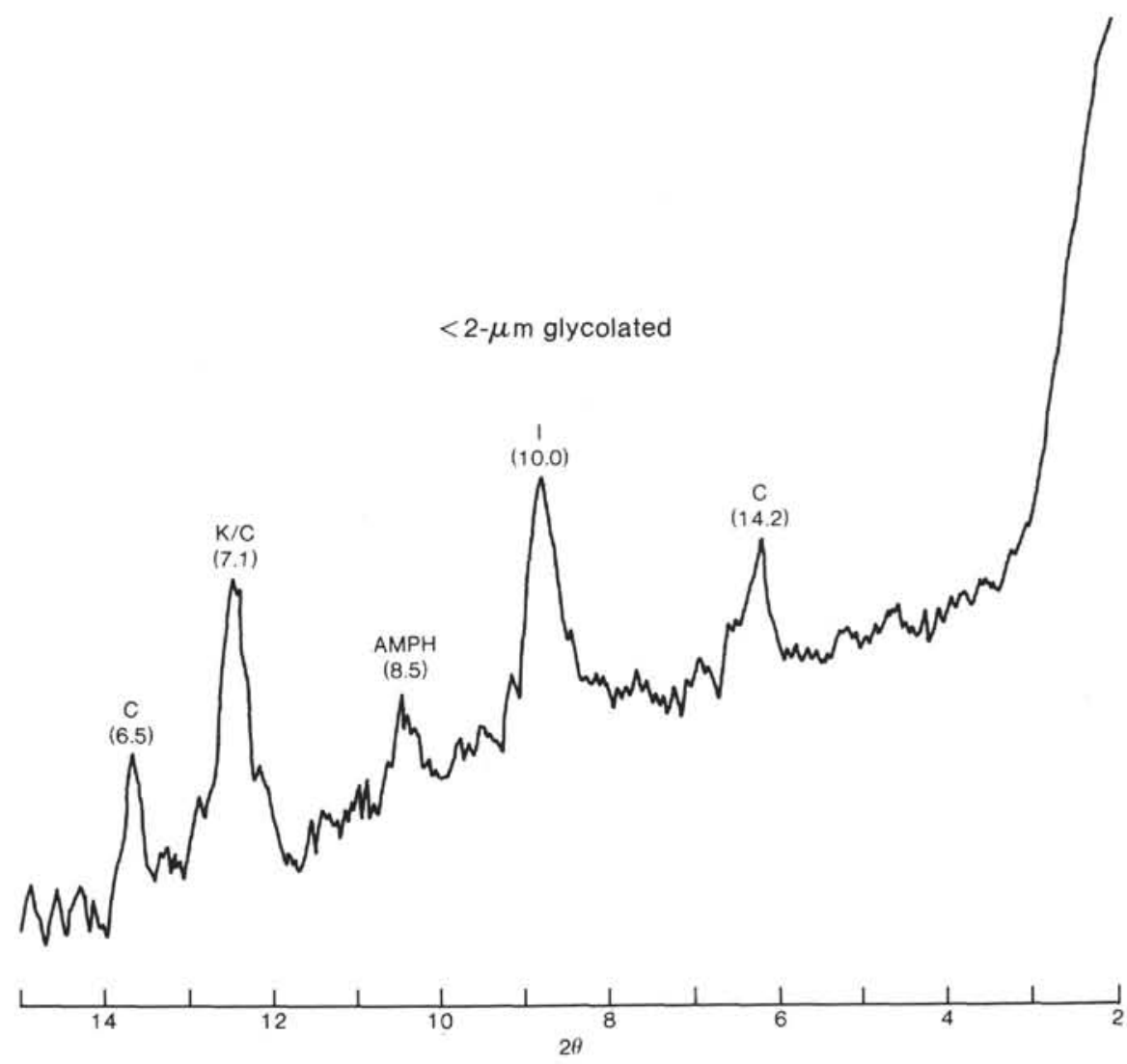

$2 \theta$

Figure 5. X-ray diffractogram of the $<2-\mu \mathrm{m}$ fraction of Sample $604-18-4,100 \mathrm{~cm}$, indicating typical 14-A chlorite (C), illite (I), and kaolinite (K) peaks seen in samples saturated with ethylene glycol. A small 8.5- $\AA$ amphibole peak (AMPH) is also seen in this diffractogram. Kaolinitechlorite proportions were estimated based on relative areas under the 3.57- and 3.54- $\AA$ peaks seen on diffractograms of oriented $<2-\mu \mathrm{m}$ samples, as shown on the left.

thaway model, which puts chlorite exclusively in the "Northern clay mineral facies." Thus it would appear that chlorite was being transported at least sporadically to the edge of the North American continent during the Paleogene, and being incorporated into marine sediments of the upper continental rise. Another difference between Site 605 mineralogy and the "Southern clay mineral facies" is the dominance of illite at Site 605 , in contrast to the predicted dominance of smectite in the "Southern facies."

\section{Comparison of Site 604 and 605 Clay Mineralogy with Other North Atlantic DSDP Sites}

The "Northern clay mineral facies" at Sites 604 and 605 is similar to the clay mineral distributions seen in Neogene-Quaternary sediments of nearby DSDP holes drilled on the lower continental rise and abyssal plains of the northwestern Atlantic Ocean. The Neogene-Quaternary clay mineralogy of Leg 93 sites is very similar to nearby DSDP Sites 388, 105, 106.

Flood (1978) found that at Site 388 in the lower continental rise hills to the southeast of the Leg 93 sites, lower Pleistocene to Recent sediments (lithologic Unit 1) contained kaolinite, illite, calcite, and quartz. Middle to late Miocene silty clays of Unit 2 contained dominant illite and smectite, with kaolinite, chlorite, quartz, and siderite also present. Flood used the presence of the "Northern clay mineral assemblage" (illite, chlorite, fine- grained quartz particles, feldspar, and hornblende; $\mathrm{Ha}$ thaway, 1972) at Site 388 as an indicator of post-Miocene erosion of Paleozoic and older sedimentary and metamorphic rocks of the northern Appalachian region due to Northern Hemisphere glaciation.

At nearby Site 105, also at the foot of the lower continental rise, to the southeast of the Leg 93 New Jersey Transect sites, Pliocene-Holocene hemipelagic muds were found to have dominant illite, with quartz, kaolinite, and smectite (Zemmels et al., 1972). Chlorite was found in the middle Miocene-Pleistocene, and the zeolite clinoptilolite was present in altered upper Oligocene to middle Miocene volcanic ash beds. Chlorite and illite were the dominant clay minerals in Pliocene to Recent sediments at Site 105, in agreement with Hathaway's (1972) "Northern clay mineral facies." Site 106, also located at the foot of the lower continental rise to the north of Site 105 , only recovered a few cores containing early to late Pleistocene sediments, but they contained illite, quartz, calcite, amphibole, chlorite, and kaolinite (Zemmels et al., 1972), with an early Pleistocene palygorskite peak. Thus Pleistocene sediments of cores recovered from Site 106 also contain Hathaway's "Northern clay mineral assemblage."

So, DSDP cores in the western North Atlantic from both the upper continental rise (Sites 604 and 605) and the lower rise (Sites 388, 105, 106) contain evidence of post-middle Miocene glacial erosion of the North Ameri- 


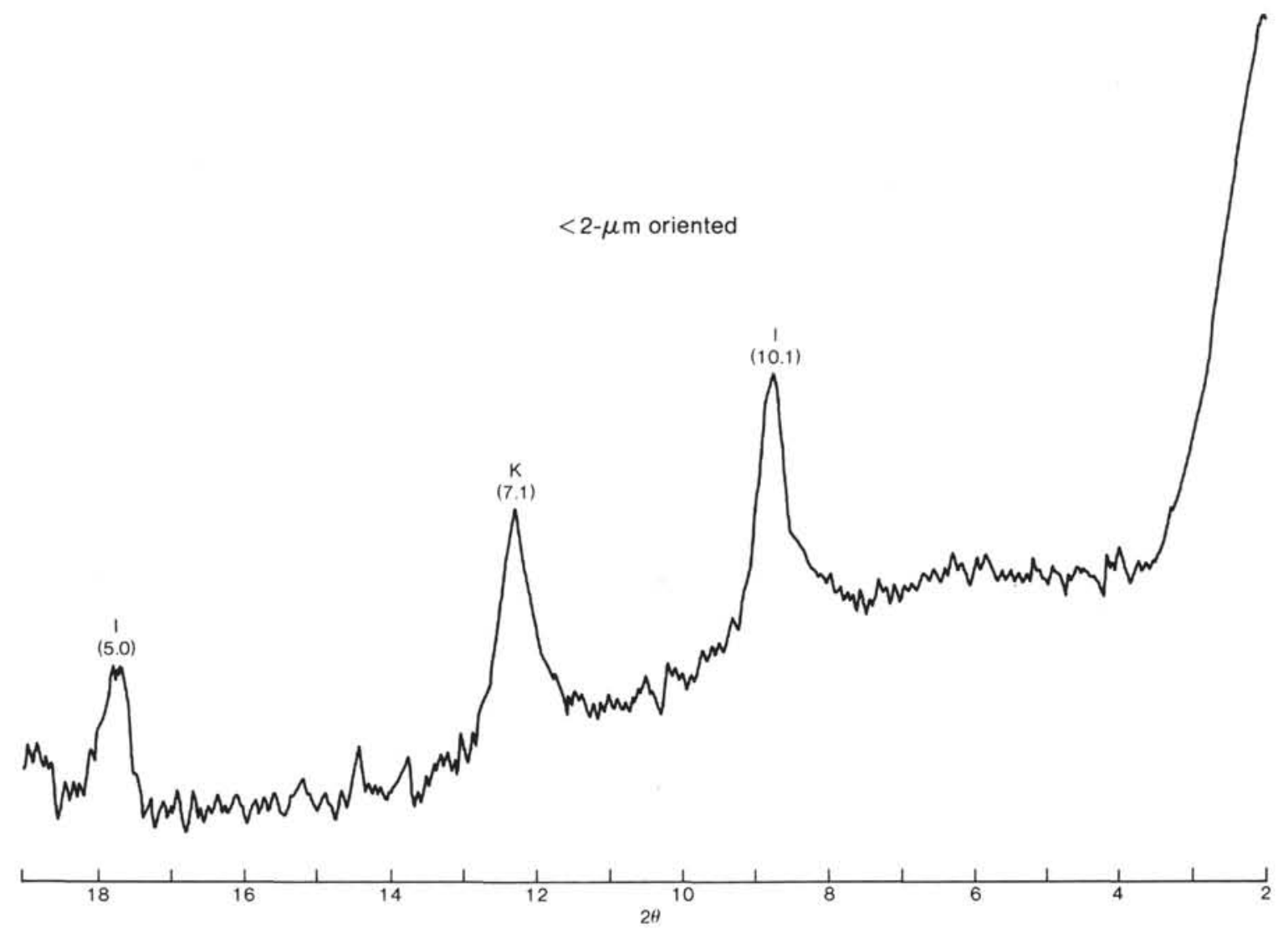

Figure 6. X-ray diffractogram of the $<2-\mu \mathrm{m}$ fraction of Sample $604-27-1,140 \mathrm{~cm}$, indicating typical peaks for illite (I) and kaolinite $(\mathrm{K})$ seen in samples of this study.

can continent, as evidenced by deposition of the "Northern clay mineral assemblage" (Hathaway, 1972) in these sediments. The dominant illite and chlorite at these sites is mixed with minor amounts of kaolinite and smectite from the "Southern clay mineral assemblage," which may have been transported northward by strong surface currents prior to deposition on the continental rise. Additional evidence of deposition of sediments derived from continental erosion at DSDP sites on the continental rise is provided by the presence of easily altered feldspar and hornblende, found both on the lower continental rise in middle to late Miocene sediments at Site 388 , in early to late Pleistocene sediments at Site 106, and also on the upper continental rise in late Pliocene to Recent sediments at Sites 604 and 605 .

A comparison between the Leg 93 New Jersey Transect Cenozoic clay mineralogy and equivalent sediments on the eastern margin of the North Atlantic Basin is possible by referring to the clay mineralogy sampled by drilling on the Moroccan continental margin by DSDP Leg 79 (Hinz, Winterer, et al., 1984). Although Leg 79 sediments contain greater amounts of calcium carbonate, because of greater upwelling off northwestern Africa (Hinz, Winterer, et al., 1984), the clay mineralogy of Leg 79 sediments is quite similar to the Sites 604 and 605 record.

Leg 79 drilled Sites 544 to 547 on the Mazagan Escarpment off northwestern Africa, and a preliminary study of the clay mineralogy of these sites was made by Schu- mann (1984). At Site 544, Holes 544A and 544B (3607 $\mathrm{m}$ water depth) recovered early middle Miocene to Pleistocene clayey foraminiferal nannofossil ooze. Clay minerals of this lithologic unit were dominated $(>50 \%)$ by illite, with minor (10-15\%) amounts of kaolinite, chlorite, and smectite. Palygorskite and sepiolite were found in rare $(2-8 \%)$ quantities in these sediments. The presence of these fibrous silicates was interpreted as resulting from downslope transport by turbidity currents from the Moroccan margin alkaline basins where they were formed. Site 545, drilled at the foot of the Mazagan Escarpment at a water depth of $3142 \mathrm{~m}$, recovered early Miocene to Pleistocene clayey foraminiferal nannofossil oozes, which were also dominated by illite, with minor $(10-15 \%)$ chlorite and kaolinite, and trace to minor $(<5 \%)$ amounts of smectite. Some mixed-layer clays (illite and chlorite/smectite) and fibrous clays (palygorskite and sepiolite) were also present at this site. The Sites 544 and 545 sedimentary records primarily contain clay minerals from the "Northern clay mineral facies" of Hathaway (1972), with dominant illite and chlorite, and trace quantities of feldspar. However, they also contain minor amounts of smectite and kaolinite, which are part of the "Southern clay mineral assemblage" of Hathaway (1972), so these sediments may represent a mixture of tropical and temperate clay mineral sources.

Site 546 was drilled atop a structural high in $3992 \mathrm{~m}$ water depth, and recovered middle Miocene to Pleistocene clayey foraminiferal-nannofossil ooze above Juras- 


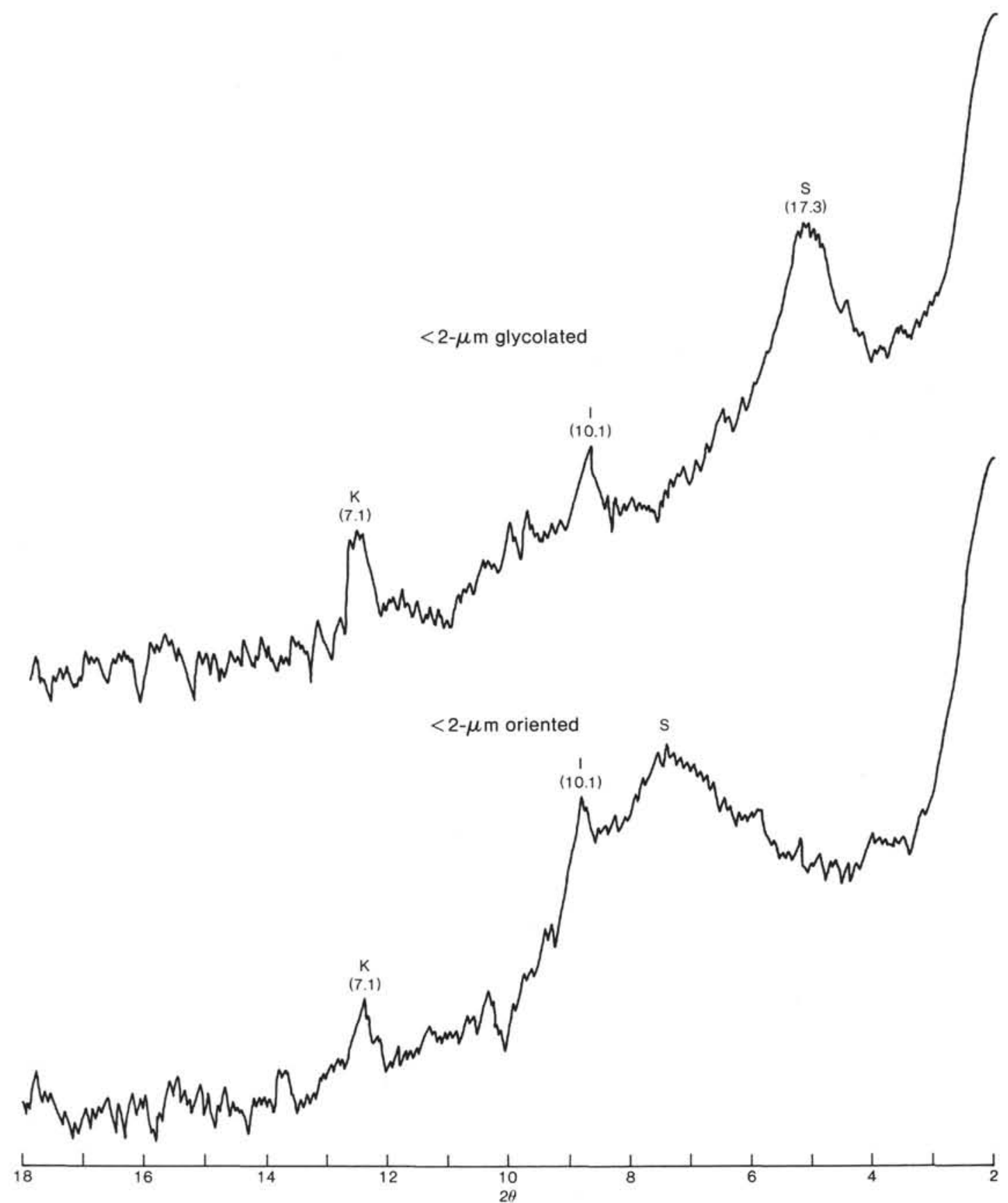

Figure 7. X-ray diffractogram of the $<2-\mu \mathrm{m}$ fraction of Sample $604-48-4,100 \mathrm{~cm}$, and the $<2-\mu \mathrm{m}$ fraction after saturation with ethylene glycol. The presence of smectite (S) is seen by a $17 \AA$ peak in the glycolated sample, whereas peaks of illite (I) and kaolinite (K) are not affected by glycolation.

sic halite and claystones. Neogene clay minerals at this site were again dominated by illite, with minor chlorite and kaolinite, and trace amounts of smectite and feldspar. No fibrous clays were found at this site. Neogene sediments at Site 546 contain clay minerals attributable to the "Northern clay mineral assemblage," and also contain trace amounts of smectite and kaolinite from the "Southern clay mineral assemblage," as did the sediments of Sites 544 and 545 .

Site 547 was drilled on the same structural block as Site 544 , but to the east-northeast, in $3940.5 \mathrm{~m}$ water depth. Site 547 recovered a relatively complete Cenozoic sedimentary section, with Late Cretaceous to early Oligocene clayey nannofossil chalk and nannofossil claystone dominated by smectite and illite, and trace amounts of kaolinite, chlorite, and feldspar. Above an early Oligocene/early Miocene unconformity, early to late Miocene clayey nannofossil ooze and Pliocene-Pleistocene foraminiferal-nannofossil ooze contained dominant illite, with minor (10-15\%) but approximately equal amounts of chlorite and kaolinite. Neogene samples at Site 547 contained minor $(10-30 \%)$ smectite in late Miocene sediments, and trace $(<5 \%)$ amounts of smectite in Pliocene-Pleistocene sediments. As at Site 546, no sepiolite 
or palygorskite was found in Cenozoic sediments from this site.

There is a strong similarity between the clay mineralogies of DSDP Site 547, on the Moroccan continental margin, and Sites 604 and 605, on the New Jersey continental margin. Sediments from both the western margin and the eastern margin of the North Atlantic Ocean demonstrate dominance of the "Southern clay mineral assemblage" (Hathaway, 1972) in Paleogene strata, with smectite and kaolinite being the dominant clay minerals. These sediments are unconformably overlain by Miocene to Recent strata whose clay mineralogy is dominated by illite and chlorite, the "Northern clay mineral assemblage." Neogene sediments in both locations also contain easily altered nonclay minerals, feldspar and amphibole, which are assumed to represent erosion of Northern Hemisphere continents by continental glaciation.

The similarity of the clay mineralogy of Leg 93 sediments and Leg 79 sediments is perhaps greater than expected, even considering that paleoreconstructions (closure of the North Atlantic Basin) would place these two sets of drill sites very close to each other. The only major difference between the clay mineralogy of the Leg 93 sites examined in this study and the Leg 79 sites (Schumann, 1984) is the lack of fibrous silicates (sepiolite and palygorskite) at Sites 604 and 605 . The fibrous silicates are neoformed clay minerals, which form in humid subtropical environments, commonly in alkaline basins. Because of the greater latitude of potential source basins for Leg 93 clay minerals, it is not likely that the conditions necessary for neoformation of these fibrous clays were present in the northeastern part of North America.

\section{CONCLUSIONS}

The sediment record recovered at Sites 604 and 605 on the New Jersey Transect agrees in general with the stratigraphic division proposed by Olsson (1978) for the eastern costal plain of the United States. At these sites, Paleocene marls and nannofossil limestones, early Eocene nannofossil chalks to limestones, and middle Eocene biogenic silica-rich nannofossil chalks are separated by a disconformity from Pliocene-Pleistocene silty clays and claystones. At Site 604 a middle to late Miocene debris-flow unit composed of glauconitic silty claystone and conglomerate, reworked Eocene chalk and limestone, and exotic pebbles to cobbles is found below the early Pliocene claystones, but this unit was deliberately avoided in the offset to drill Site 605 .

The clay mineralogy of these Leg 93 sites agrees in general with the model proposed by Hathaway (1972), which designates a "Northern clay mineral assemblage" composed of illite and chlorite, with associated feldspar and hornblende, and a "Southern clay mineral assemblage" composed of smectite and kaolinite, with mixedlayer illite-smectite clay minerals. The "Northern assemblage" is found in Leg 93 sediments atop the uppermost middle Eocene to middle Miocene disconformity, and the "Southern assemblage" typifies the Paleogene sediments at both sites. The clay mineral distribution and stratigraphy of Sites 604 and 605 agrees with the stratigraphies of nearly DSDP sites drilled on the lower conti- nental rise and abyssal plains of the western North Atlantic (DSDP Sites 388, 105, and 106). The clay mineral stratigraphy of this study is also similar to the clay mineral stratigraphy of DSDP Leg 79 sites (544-547) drilled on the Mazagan Escarpment off northwestern Morocco, with the exception that fibrous clay minerals (sepiolite and palygorskite) seen at Leg 79 sites are not found at Sites 604 and 605 . The absence of the fibrous clays is probably due to the lack of humid alkaline nearshore basins necessary for the neoformation of these fibrous silicates. Thus an apparent similarity may be noted between the clay mineralogy of the western and the eastern margins of the Cenozoic North Atlantic Ocean by comparing the records of Legs 93 and 79.

\section{ACKNOWLEDGMENTS}

We thank our colleagues M. A. Meylan, W. Hughes, S. Rahaim, G. Bonn, and W. C. Pettway for valuable discussions and technical assistance in the XRD analyses made in this study. The senior author thanks the Deep Sea Drilling Project for the invitation to participate on Leg 93 as Shipboard Science Representative and Sedimentologist, and for partial financial assistance during the analyses and preparation of the manuscript. He also would like to thank his Leg 93 shipmates Jay Muza, Phil Meyers, and Mark Johns for valuable discussions, as well as his graduate students for acquiescing to the benign neglect made necessary by the editorial demands of Volume 93 . This manuscript has been substantially improved by the critical reviews of Maurice A. Meylan, John C. Hathaway, and Ray E. Ferrell, Jr.

\section{REFERENCES}

Anguita, F., and Hernan, F., 1975. A propagating fracture model versus a hot spot origin for the Canary Islands. Earth Planet. Sci. Lett., 27:11-19.

Asquith, S. M., 1979. Nature and origin of the lower continental rise hills off the East Coast of the United States. Mar. Geol., 32:165190.

Biscaye, P. E., 1965. Mineralogy and sedimentation of recent deep-sea clay in the Atlantic Ocean and adjacent seas and oceans. Geol. Soc. Am. Bull., 76:803-831.

Brown, G. (Ed.), 1961. The X-Ray Identification and Crystal Structures of Clay Minerals: London (The Mineralogical Society [Clay Minerals Group]).

Carroll, D., 1970. Clay Minerals: A Guide to Their X-Ray Identification: Boulder, Colorado (Geol. Soc. Am., Special Paper No. 126).

Carver, R. E., 1971. Procedures in Sedimentary Petrology: New York (Wiley-Interscience, John Wiley and Sons, Inc.).

Chamley, H., Debrabant, P., Candillier, A. -M., and Foulon, J., 1983. Clay mineralogy and inorganic geochemical stratigraphy of BlakeBahama Basin since the Callovian, Site 534, Deep Sea Drilling Project Leg 76. In Sheridan, R. E., Gradstein, F. M., et al., Init. Repts. DSDP, 76: Washington (U.S. Govt. Printing Office), 437-451.

Flood, R. D., 1978. X-Ray mineralogy of DSDP Legs 44 and 44A, Western North Atlantic: lower continental rise hills, Blake Nose, and Blake-Bahama Basin. In Benson, W. E., Sheridan, R. E., et al., Init. Repts. DSDP, 44: Washington (U.S. Govt. Printing Office), 515-521.

Gradstein, F., and Sheridan, R. E. 1983. On the Jurassic Atlantic Ocean and a synthesis of results of Deep Sea Drilling Project Leg 76. In Sheridan, R. E., Gradstein, F. M., et al., Init. Repts DSDP, 76: Washington (U.S. Govt. Printing Office), 913-943.

Haq, B. U., and Lohmann, G. P., 1976. Early Cenozoic calcareous nannoplankton biogeography of the Atlantic Ocean. Mar. Micropaleontol., 1:119-194.

Hathaway, J. C., 1972. Regional clay mineral facies in estuaries and continental margins of the United States East Coast. Geol. Soc. Am. Mem., 133:293-316.

Heezen, B. C., Hollister, C., and Ruddiman, W. F., 1966. Shaping of the continental rise by deep geostrophic contour currents. Science, 152:502-508. 
Hinz, K., Winterer, E. L., et al., 1984. Init. Repts DSDP, 79: Washington (U.S. Govt. Printing Office).

Houghton, R. L., Thomas, J. E., Jr., Diecchio, R. J., and Tagliacozzo, A., 1979. Radiometric ages of basalts from DSDP Leg 43: Sites 382 and 385 (New England Seamounts), 384 (J-Anomaly), 386 and 387 (Central and Western Bermuda Rise). In Tucholke, B. E., Vogt, P. R., et al., Init. Repts DSDP, 43: Washington (U.S. Govt. Printing Office), 739-753.

Ingle, J. C., Jr., Graham, S. A., and Dickinson, W. R., 1976. Evidence and implications of worldwide late Paleogene climatic and eustatic events. Geol. Soc. Am., Abstracts with Programs, 9,(7): 934-935.

Jansa, L. F., Enos, P., Tucholke, B. E., Gradstein, F., and Sheridan, R. E., 1979. Mesozoic-Cenozoic sedimentary formations of the North American Basin; western North Atlantic. In Talwani, W., Hay, W., and Ryan, W. B. F. (Eds.), Deep Sea Drilling Results in the Atlantic Ocean: Continental Margins and Paleoenvironment. Am. Geophys. Union, Maurice Ewing Series, 3:1-57.

Kastner, M., 1979. Silica polymorphs. In Burns, R. G. (Ed.), Marine Minerals Short Course Notes (Vol. 6):Washington, D. C. (Mineralogical Soc. Am.), 99-109.

Lancelot, Y., Hathaway, J., and Hollister, C., 1972. Lithology of sediments from the western North Atlantic. In Hollister, C. D., Ewing, J. I., et al., Init. Repts. DSDP, 11: Washington (U.S. Govt. Printing Office), 901-950.

MacDougall, D., 1971. Deep-sea drilling: age and composition of an Atlantic basaltic intrusion. Science, 171:1244.

Millot, G., 1970. Geology of Clays: New York (Springer-Verlag).

Olsson, R. K., 1978. Summary of lithostratigraphy and biostratigraphy of Atlantic coastal plain (northern part). In Benson, W. E., Sheridan, R. E., et al., Init. Repts. DSDP, 44: Washington (U.S. Govt. Printing Office), 941-947.
Reynolds, R. C., Jr., and Hower, J., 1970. The nature of interlayering in mixed-layer illite-montmorillonites. Clays Clay Mineral., 18:2536.

Schumann, D., 1984. Mineralogy of Cenozoic sediments cored during Deep Sea Drilling Project Leg 79 as determined by X-ray diffraction. In Hinz, K., Winterer, E. L., et al., Init. Repts. DSDP, 79; Washington (U.S. Govt. Printing Office), 395-398.

Tucholke, B. E., 1979. Relationships between acoustic stratigraphy and lithostratigraphy in the western North Atlantic Basin. In Tucholke, B. E., Vogt, P. R., et al., Init. Repts. DSDP, 43: Washington (U.S. Govt. Printing Office), 827-846.

Tucholke, B. E., Vogt, P. R., et al., 1979. Init. Repts DSDP, 43: Washington (U.S. Govt. Printing Office).

Vail, P. R., Mitchum, R. M., Jr., and Thompson, S., III, 1977. Seismic stratigraphy and global changes of sea level, Part 4: global cycles of relative changes of sea level. In Payton, C. E. (Ed.), Seismic Stratigraphy-Applications to Hydrocarbon Exploration. Am. Assoc. Pet. Geol. Mem., 26:83-97.

Vogt, P. R., and Tucholke, B. E., 1979. The New England Seamounts: testing origins. In Tucholke, B. E., Vogt, P. R., et al., Init. Repts. DSDP, 43: Washington (U.S. Govt. Printing Office), 847-856.

Weaver, F. M., and Dinkelman, M. G., 1978. Cenozoic radiolarians from the Blake Plateau and the Blake-Bahama Basin, DSDP Leg 44. In Benson, W. E., Sheridan, R. E., et al., Init. Repts. DSDP, 44: Washington (U.S. Govt. Printing Office), 865-885.

Zemmels, I., Cook, H. E., and Hathaway, J. C., 1972. X-ray mineralogy studies, Leg 11. In Hollister, C. D., Ewing, J. I., et al., Init. Repts. DSDP, 11: Washington (U.S. Govt. Printing Office), 729-789.

Date of Initial Receipt: 5 August 1985

Date of Acceptance: 30 June 1986 